\title{
The potential bio-conversion of Palm Oil Mill Effluent (POME) as Bioethanol by steady-state anaerobic processes
}

\author{
Muh. Ilham Anggamulia1, Mindriany Syafila1, Marisa Handajani1 and Andri Gumilar1 \\ 1Department of Environmental Engineering, Institute Technology Bandung, Jl. Ganesa No 10 Bandung, Indonesia
}

\begin{abstract}
Biomass is a central issue as new material that can be used as a substrate to produce biofuels, it has become global research to replace liquid fossil fuels with alternative renewable and sustainable fossils. Palm oil mill effluent (POME) is the potential of Agriindustrial waste to be used as alternative energy with anaerobic digestion of high concentration organic wastewater can be used for bioethanol production to replace food as raw material. Bioethanol can be produced in acidogenic steps in the organic degradation process. In this research, bacterial mixed cultures sourced from bovine rumen as biomass and the substrate used was palm oil mill effluent (POME) with a characteristic COD concentration of $25,600 \mathrm{mg} / \mathrm{L}$, The operation of the reactor is set at $\mathrm{pH} 5 ; 6 ; 7$ for 72 hours with the type of anaerobic circulating batch reactor (CBR), measurement of bioethanol products and acidogenesis of samples is carried out every 6 hours. The results showed that the reactor with variations in $\mathrm{pH}$ conditions 5 gave the highest efficiency of bioethanol formation in the 12 hour running process, result is $102,94 \mathrm{mg} / \mathrm{L}$ with a maximum formation rate of $9,98 \mathrm{mg} / \mathrm{L} /$ hour.
\end{abstract}

\section{Introduction}

The future of manufacturing production lies in the sustainability of biofuel supply, competition from greener production has become a global qualification. Biofuel has high competitiveness as an alternative because it has the advantage of fossil fuels, namely pollution that does not pollute the environment. Bioethanol, bio-hydrogen, biogas are renewable biofuels with high-quality fuel properties and can be used for a variety of energy services [1] Bioconversion of wastewater with high organic concentrations by anaerobic process can be produced biofuels which is can instead of fossil fuels [2]. Renewable resources including agricultural and industrial residues have been studied through microbial bioconversion processes.

One of the largest exporters of palm oil is Indonesia, besides processing it produces biomass from palm oil waste, which is located in several regions such as Sulawesi, Kalimantan, Java and Sumatra [3]. The majority of Indonesia (30,5 million tons) contributed to palm oil in the world and thereafter and Malaysia (19,9 million tons)

[4]. The byproducts of high concentration organic waste from the palm oil process are currently not optimally utilized, for example, wastewater treatment releases methane gas into the environment around $32,9 \mathrm{~kg} / \mathrm{ton}$ of palm oil produced [5].

The Previous research has been shown that wastewater high organic content can be used as a substrate and bacterial mixed cultures anaerobic for bioethanol production using anaerobic processes. High organic concentrations, found in palm oil industry wastewater such as carbohydrates, proteins, nitrogen compounds, oils and fats, high mineral content, and other organic compounds, such as cellulose, hemicellulose, and starch

[6]. with COD and POME content around 44.300-

$102.696 \mathrm{mg} / \mathrm{L}$ and 25.000-65.714 mg / L [7].
Biofuel production such as ethanol and hydrogen can be obtained from the bioconversion of wastewater with high organic content [8]. There are four stages of the anaerobic process pathway, namely hydrolysis, acidogenesis, acetogenesis, and methanogenesis [9]. Ethanol and other derivative products are formed during the acidogenic phase. As mentioned before, ethanol produced by bacterial mixed cultures Anaerobic will be followed by various products side, so as to increase efficiency ethanol formation hence product formation the side must be minimized. In general, yield products are not only influenced by the rate and growth of fermentation but the $\mathrm{pH}$ of the medium is also involved [10] Some research results state optimal conditions ethanol formation by mixed culture bacteria anaerobic on molasses and or glucose substrate occur in the $\mathrm{pH}$ range 4-5 $[11,12,13,14], \mathrm{pH}$ range 5-5.5 [15,16,17], and a $\mathrm{pH}$ range of $6-8[18,19,20]$. However, in the complex substrate containing starch, protein and oil/fat that has not been much studied, so in this study, the characteristics of palm oil mill effluents (POME) that exist aim to further determine the effect of $\mathrm{pH}$ control on bioethanol formation from the characteristics of palm oil mill effluents (POME) which have been analyzed

\section{Materials and Methods}

\subsection{Organic biomass and wastewater}

The raw biomass in this study came from PT. Condong, Garut, Indonesia. Cow's rumen is mixed with biomass at a ratio of 50:50 with the most concentrated concentration used for anaerobic reactors in the case of suspended solid volatile mixed alcohol (MLVSS) and mixed liquid suspended solid (MLSS) around $3680 \mathrm{mg} / \mathrm{L}$ and $725 \mathrm{mg} / \mathrm{L}$ respectively 


\subsection{Analytical methods and reactor}

Standard methods [21] are used to identify chemical oxygen demand (COD), biological oxygen demand (BOD), pH, TSS, and total nitrogen while bioethanol is measured using GC Shimadzu 2010 with fire-ionization detection (GC-FID) with column DB-wax (prophylene glycol)(30m x 0,25mm)

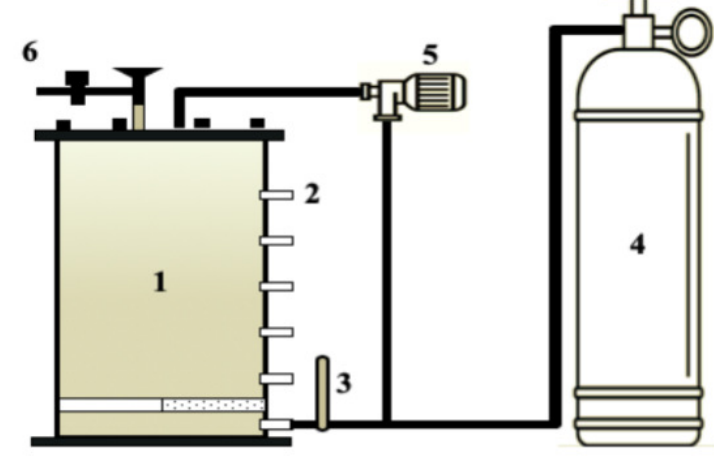

Note:

1. Anaerobic reactor; 2. Sampling port; 3. Flow meter; 4. Gas N2; 5. circulation pump; 6. Gas ventilation

Fig 1. Schematic of lab-scale of anaerobic circular batch reactor $(\mathrm{CBR})$

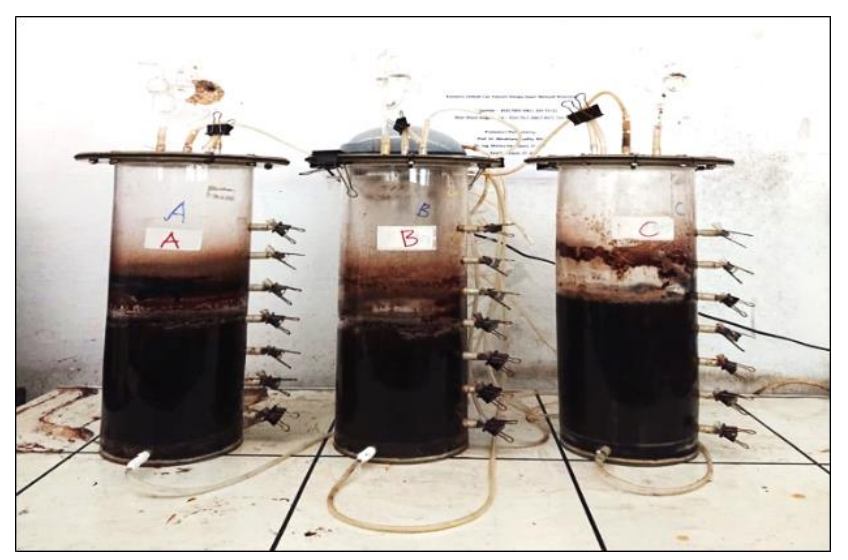

Fig 2. Real of lab-scale of anaerobic circular batch reactor $(\mathrm{CBR})$

\subsection{Experimental method}

The operation of the reactor was conditioned at $5 \mathrm{~L}$ working volume for 72 hours by internal biogas by rinsing N2 1L / min for 24 hours (Figure 1) with a mixture consisting of $80 \%$ (v / v) or 4 liters of POME as a substrate, and $20 \%$ (v) / $\mathrm{v})$ or 1 liter of mixed culture bacteria, for further processing anaerobically. For experimental design reactors (A) the $\mathrm{pH}$ setting value of 5 conditions; reactor

(B) setting value 6 conditions, reactor (C) setting value 7 conditions with each treatment the same.

\subsection{Calculation}

Mass balance analysis can provide the amount of substrate converted for fermentation production, as well as the influence of $\mathrm{pH}$ conditions and the substrate can be used for the production of sterilized fermentation in the bioethanol formation pathway. The analysis is calculated by converting each acidogenic product as a theoretical dissolved COD equivalent to Van Haandeland's Van Der Lubbe (2012) showing in equation 1

$\mathrm{COD}_{\text {theoritical }}=$

$$
8 \cdot(4 x+y-2 z) /(12 x+y+16 z) \text { gCOD.g-1 } \mathrm{CxHyOz}
$$

where:

$\mathrm{x}=\mathrm{C} ; \mathrm{y}=\mathrm{H}$ and $\mathrm{z}=\mathrm{O}$.

$$
\mathrm{DE}=\overline{\frac{(\mathrm{Ethanol})}{\text { influent of soluble COD }}} \frac{[\mathrm{mgCOD} / \mathrm{L}]}{[\mathrm{mgCOD} / \mathrm{L}]}
$$

$\mathrm{DE}=$ Degree of ethanofication

$$
\mathrm{DA}=\frac{(\text { Total wolatilacid) }}{\text { influent of soluble COD }} \frac{[\mathrm{mgCOD} / \mathrm{L}]}{[\mathrm{mgCOD} / \mathrm{L}]}
$$

DA $=$ Degree of acidification

Formation rate product (mgCOD/L/hour)

$\frac{\left[\text { Product concentration }_{\text {end }}-\text { Initial concentration }_{\text {in }}\right]}{\text { time }} \frac{[\mathrm{mgCOD} / \mathrm{L}]}{[\mathrm{hour}]}(4)$

\section{Result and discussion}

In this study, the wastewater used by the palm oil mill industrial waste product, is then analyzed to determine the basic characteristics of wastewater. The results of wastewater analysis can be seen in table $\mathbf{1}$ compared to other experiments in table $\mathbf{2}$ with the same substrate but different $\mathrm{pH}$ conditions. The waste used has a total COD concentration and dissolved COD is $25,600 \mathrm{mg} / \mathrm{L}$ and $5,600 \mathrm{mg} / \mathrm{L}$. The waste is then put into the circulating bed reactor.

Table 1. Characteristic of POME in experiment

\begin{tabular}{llr}
\hline Parameter & Unit & Results \\
\hline Total COD & $\mathrm{mg} / \mathrm{L}$ & 25.600 \\
Soluble COD & $\mathrm{mg} / \mathrm{L}$ & 5.600 \\
$\mathrm{pH}$ & - & 3,92 \\
$\mathrm{TSS}$ & $\mathrm{mg} / \mathrm{L}$ & 4.405 \\
Volatile fatty acid & $\mathrm{mg} / \mathrm{L}$ & 69.802 \\
Nitrogen Total & $\mathrm{mg} / \mathrm{L}-\mathrm{N}$ & 224 \\
Oil and Grease & $\mathrm{mg} / \mathrm{L}$ & 487 \\
BOD & $\mathrm{mg} / \mathrm{L}$ & 7.600 \\
\hline
\end{tabular}

Table 2. Characteristic of POME in other experiment [22]

\begin{tabular}{llc}
\hline Parameter & Unit & Results \\
\hline $\mathrm{pH}$ & - & 6,52 \\
Total COD & $\mathrm{mg} / \mathrm{L}$ & 6.515 \\
Soluble COD & $\mathrm{mg} / \mathrm{L}$ & 2.816 \\
Oil and Grease & $\mathrm{mg} / \mathrm{L}$ & 4.210 \\
VSS & $\mathrm{mg} / \mathrm{L}-\mathrm{N}$ & 1.630 \\
BOD & $\mathrm{mg} / \mathrm{L}$ & 4.750 \\
\hline
\end{tabular}




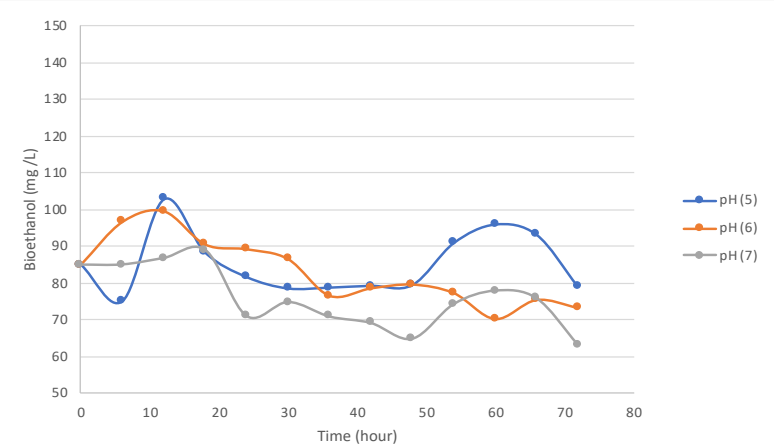

Fig 3. Bioethanol formation from the variation of $\mathrm{pH}$

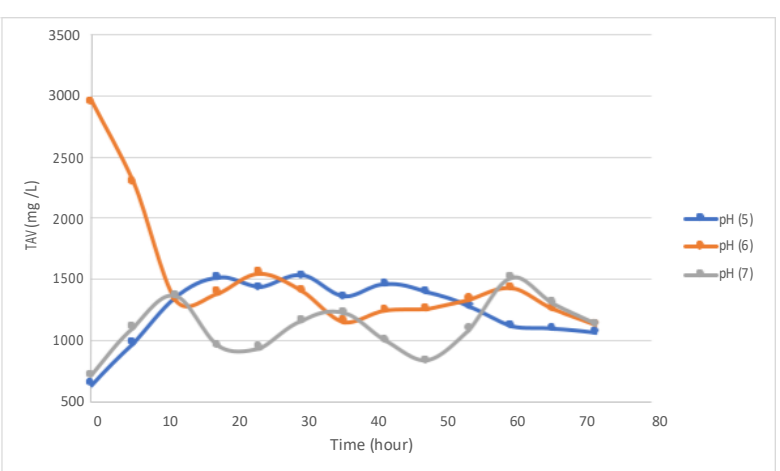

Fig 4. Total volatile acid formation from $\mathrm{pH}$ condition

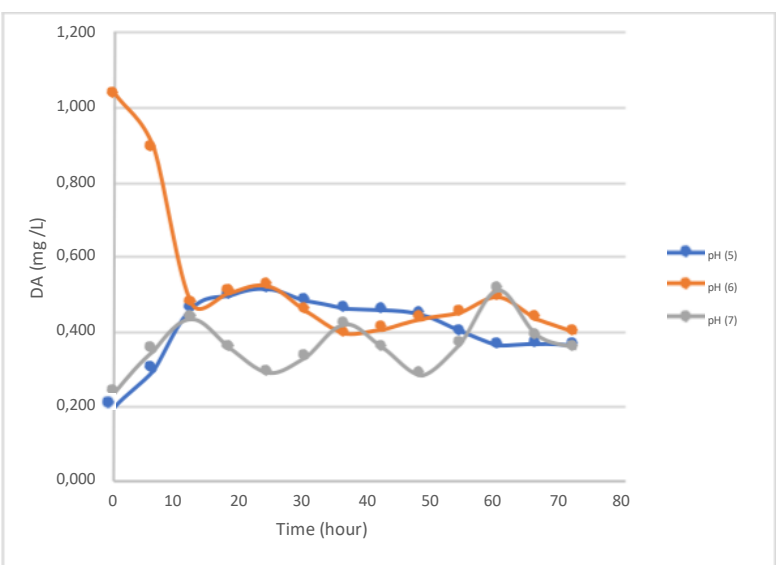

Fig 5. Degree acidification formation from $\mathrm{pH}$ condition

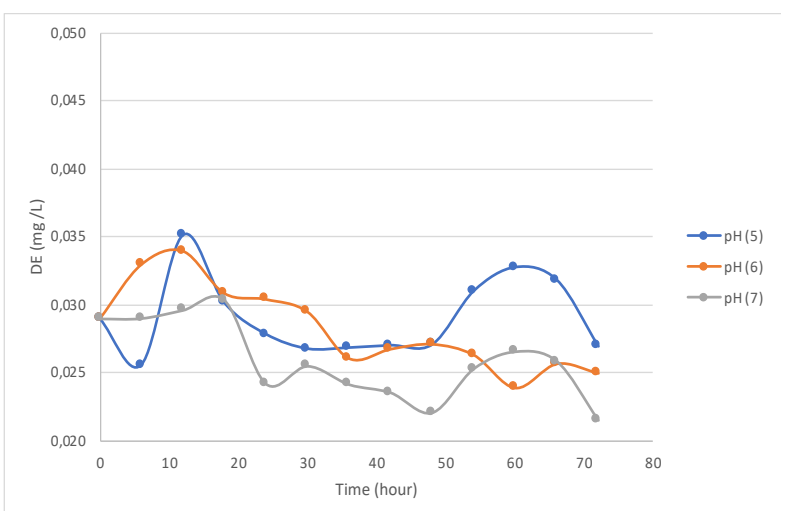

Fig 6. Degree ethanofication from $\mathrm{pH}$ condition
In Figure 3 - 6 shows that the general increase in the concentration of bioethanol, total volatile acid, degree acidification and degree ethanolfication in each reactor. Bioethanol was start to produced after $12 \mathrm{hr}$ for each reactor with variation condition in $\mathrm{pH}$. Highest bioethanol production occurs at the reactor with variation of $\mathrm{pH} 5$ is $102,94 \mathrm{mg} / \mathrm{L}$ with degree of ethanolfication (DE) is 0,035 $\mathrm{mgCOD} / \mathrm{L}$ the maximum rate of bioethanol production is $9,98 \mathrm{mg} / \mathrm{L} / \mathrm{hr}$. The concentration of bioethanol increased until 12-hr, then after 24-hr to $48 \mathrm{hr}$ bioethanol concentration are stable at 88,24 to $93,19 \mathrm{mg} / \mathrm{L} \mathrm{In}$ other variations, typical of bioethanol production is the same, bioethanol concentration was increased until 12 and then stable from then after 24 to $48 \mathrm{hr}$. Bioethanol production for another conditions in $\mathrm{pH} 6$ and 7 have lower concentration than the reactor with $\mathrm{pH} 5$ condition, The highest concentration of bioethanol in $\mathrm{pH} 6$ is $99,44 \mathrm{mg} / \mathrm{L}$ by the rate of bioethanol production is $-1,03 \mathrm{mg} / \mathrm{L} / \mathrm{hr}$. At pH 7 conditions the highest concentration of bioethanol production in the reactor was $88,85 \mathrm{mg} / \mathrm{L}$ with a bioethanol production rate of $0,17 \mathrm{mg} / \mathrm{L} / \mathrm{hour}$. Environmental factors provide a fluctuating influence on bioethanol formation such as the presence of enzyme modulator, temperature, $\mathrm{pH}$, and dissolved oxygen [22], nitrogen flushing can shift metabolism pathway to be acetyl CoA production then it will be oxidized to be bioethanol by alcohol dehydrogenase enzyme [23].

The $\mathrm{pH} 5$ condition has been previously studied [24] bioethanol production $237,13 \pm 25,86 \mathrm{mg} / \mathrm{L}$, achieved at an HRT of $9 \mathrm{~h}$ using mixed culture bacteria harvested from a waste treatment plant located in Al-Agamy, Alexandria, Egypt. Besides that, the other condition of $\mathrm{pH}$ 6 had been studied previously [24] from same substrate combined with metal ions and N2 flushing for 24 hours produced the highest concentration of bioethanol is 78,83 $\mathrm{mg} / \mathrm{L}$ with the maximum rate is $3,92 \mathrm{mg} / \mathrm{L} / \mathrm{hr}$. In this study, the same conditions of $\mathrm{pH} 5$ obtained by bioethanol are smaller because of different substrate sources but from the same substrate source, the $\mathrm{pH} 6$ obtained by greater bioethanol is $212,14 \mathrm{mg} / \mathrm{L}$ by the rate of bioethanol production is $2,59 \mathrm{mg} / \mathrm{L} /$ day.

\section{Conclusion}

Based on the results of this study, the $\mathrm{pH} 5$ effect on the formation of bioethanol. From the characteristics of POME waste, it showed that the optimum time for bioethanol formation was 12 hours with a degree of ethanolfication (DE) of $0.035 \mathrm{mgCOD} / \mathrm{L}$ and bioethanol growth rate of $9,98 \mathrm{mg} / \mathrm{L} /$ hour so that the bioethanol yield was $102,94 \mathrm{mg} / \mathrm{L}$. During the process, it not only produces bioethanol but also produces volatile acids. It means the palm mill effluent has the potential to be developed in bioconversion of renewable fuels.

\section{Acknowledgments}

This research was supported by the fund from Research Program, Community Service, and Innovation (P3MI) of Water and Wastewater Engineering Research Group 2019. 


\section{References}

[1]. Mshandete, A. M., \& Parawira, W. (2009). Biogas technology research in selected sub-Saharan African countries - A review. African Journal of Biotechnology, 8 (2), 116-25.

[2]. Salihu, A., \& Alam, M. Z. (2012). Palm oil mill effluent: a waste or a raw material? Journal of Applied Sciences Research , 8 (1), 466-73

[3]. Tree Crop Estate Statistic of Indonesia, Palm oil Indonesia (2016) Area and Palm Oil Production of Smallholder By Province and Tree Crop Classification 9-18.

[4]. Ahmed, Y., Yaakob, Z., Akhtar, P., \& Sopian, K. (2015). Production of biogas and performance evaluation of existing treatment processes in palm oil mill effluent (POME). Renewable and Sustainable Energy Reviews , 42, 1260-78.

[5]. Schuchardt, F., Wulfert, K., Darnoko, D., \& Herawan, T. (2007). Effect of new palm oil mill processes on the EFB and POME utilisation. Proceedings of Chemistry and Technology Conference PIPOC 2007, (pp. 44-57). Kuala Lumpur.

[6]. A-Shorgani, N.K.N., Shukor, H., Abdeshahian, P., Yusuf, M., Nazir, M., Kalil, M.S., Hamid, A.A., Mohtar, W., Yusoff, W., Process optimization of butanol production by Clostridium saccharoperbutylacetonicum N1-4 (ATCC 13564) using palm oil mill effluent in acetone- butanolethanol fermentation, Biocatalysis and Agricultural Biotechnology, 4, pp. 244-249, 2015.

[7]. Ji, C M and Poh, P E., Biogas from palm oil mill effluent (POME) : Opportunities and challenges from Malaysia's perspective, Renewable and Sustainable Energy Reviews, 26, pp. 717-726, 2013.

[8]. Salihu, A and Alam, M., Palm oil mill effluent: a waste or a raw material?, Journal of Applied Sciences Research, 1, pp. 466-473, 2012.

[9]. Demirel, B and Scherer, The roles of acetotrophic and hydrogenotrophic methanogens during anaerobic conversion of biomass to methane: a review, Rev Environ Sci Biotechnol, 7, pp. 173190, 2008.

[10]. Zhang, Y., Zhang, Z., Suzuki, K., \& Maekawa, T. (2003): Uptake and mass balance of trace metals for methane producing bacteria. Biomass and Bioenergy (25), 427-433.

[11]. Wang, L., Zhou, Q., \& Li, F. (2006): Avoiding propionic acid accumulation in the anaerobic process for biohydrogen production. Biomass and Bioenergy (30), 177-182.

[12]. Wang, X. J., Ren, N. Q., Xiang, W. S., \& Guo, W. Q. (2007): Influence of gaseous end-products inhibition and nutrient limitations on the growth and hydrogen production by hydrogen-producing fermentative bacterial B49. International Journal of Hydrogen Energy (32), 748-754

[13]. Yu, H.Q., dan Fang, H.H.P., 2003. Acidogenesis of Gelatin-rich Wastewater in an up flow Anaerobic
Reactor: Influence of $\mathrm{pH}$ and Temperature. Water Research, (37):55-66.

[14]. Ren, N., Wang, B., \& Huang, J. C. (1997): Ethanol-type fermentation from carbohydrate in high rate acidogenic reactor. Biotechnology Bioengineering, 54(5), 428-433.

[15]. Ren, N.Q., Xing, D., Rittmann, B.E., Zhao, L., Xie, T., dan Zhao, X., 2007. Microbial Community Structure of Ethanol Type Fermentation in Biohydrogen Production. Environmental Microbiology, 9(5):1112-1125.

[16]. Ren, N.Q., Chua, H., Chan, S.Y., Tsang, Y.F., Wang, Y.J., dan Sin, N., 2006. Assessing Optimal Fermentation Type for Bio-hydrogen Production in Continuous-Flow Acidogenic Reactors. Bioresource Technology, 98(9): 1774-1780.

[17]. Han, S.K., Kim. H.S., Sung, S., dan Shin, H.S., 2003. Effect of $\mathrm{pH}$ and Repeated Heat-Shock Treatment on Hydrogen Fermentation of Sucrose by a Mixed Culture. Env. Eng. Res. Korean Society of Environmental Engineers. 8(4):202-211.

[18]. Lu, X., Li, Y., Duan, Y., Shi, Z., dan Mao, Z., 2003. A Novel, Repeated Fed-Batch, Ethanol Production System with Extremely Long-Term Stability Achieved by Fully Recycling Fermented Supernatants, Biotechnology Letters, 25:18191826.

[19]. Temudo, M.F., Poldermans, R., Kleerebezem, R., dan van Loosdrecht, M.C.M., 2008. Glycerol Fermentation by (Open) Mixed Cultures: A Chemostat Study. Biotechnology and Bioengineering, 100(6):1088-1098.

[20]. Fang, H.H.P., dan Liu, H., 2002. Effect of pH on Hydrogen Production from Glukosa by a Mixed Culture. Bioresource Technology, 82:87-93

[21]. APHA, AWWA, WEF. (2012). Standard Method for the Examination Water and Wastewater (22nd Edition). Washington DC, United States of America: American Public Health Association.

[22]. Cao, W. \& Liu, R. (2012). Screening and optimization of trace elements supplement in sweet sorghum juice for ethanol production. Biomass and bioenergy, 50,45-51

[23]. Ohimain, E. I., \& Izah, S. C. (2017). A review of biogas production from palm oil mill effluents using different configurations of bioreactors. Renewable and Sustainable Energy Reviews , 70, 242-253.

[24]. Elreedy, A., Tawfik, A., Enitan, A., Kumari, S., dan Bux, F. (2016): Pathways of 3-biofules (hydrogen, ethanol and methane) production from petrochemical industry wastewater via anaerobic packed bed baffled reactor inoculated with mixed culture bacteria, Energy Conversion and Management, 122, 119-130.

[25]. Handajani, Gumilar, A., M., Syafila, M., Ethanol producion from the conversion of palm oil mill effluent by anaerobic process: Influence of iron (II) addition for acidogenic product formation, International Seminar of "NIT, Gifu College" and Partner Universities - Environmental Sustainability, 
Disaster Prevention and Reduction, and Engineering Education. Gifu, Japan (March 18th 19th 2018) 